\title{
PENGARUH KOMPETENSI DAN KOMITMEN PENYIDIK TERHADAP PENYELESAIAN KOMPLAIN KELUARGA/KORBAN DALAM PENANGANAN PERKARA OLEH ANGGOTA RESKRIM POLRES LAMPUNG UTARA
}

\author{
Oleh: \\ Agus Wantoro
}

\begin{abstract}
The aim of this research is to explore the influence of the competence and commitment of an investigators or an assistant investigator in the investigation process. The result shows that both of competence and commitment of an investigator or an assistant investigator have a significant relationship with the settlement of complaints. Competence has a strong enough influence with the resolution of complaints while the family has committed a weak influence on the family settlement of complaints/victims. Research findings indicate that the resolution of victim complaints will be good if the competence and commitment of investigators increased.
\end{abstract}

Keywords: An investigator, victim

\section{A. Pendahuluan}

Kepolisian Negara Republik Indonesia (Polri) merupakan sub bagian dari suatu institusi besar yang disebut pemerintahan negara. Sebagaimana yang tercantum dalam Amandemen UndangUndang Dasar Negara Indonesia Tahun 1945 pada Pasal 30 ayat (4) yang menyatakan bahwa "...Kepolisian Negara Republik Indonesia sebagai alat negara yang menjaga keamanan dan ketertiban masyarakat bertugas melindungi, mengayomi, melayani masyarakat, serta menegakkan hukum." Hal tersebut lebih ditegaskan lagi di dalam Undang-Undang Republik Indonesia Nomor 2 Tahun 2002 tentang Kepolisian Negara Republik Indonesia pada Pasal 1 ayat (1) disebutkan bahwa “...Kepolisian Negara Republik Indonesia adalah alat negara." Sebagai bagian dari suatu institusi besar tersebut Polri harus menjalankan apa yang mejadi porsinya dan tuntutan secara

Yustisia Vol.1 No.1 Januari - April 2012 umum terhadap setiap lembaga pemerintahan negara. Tuntutan yang saat ini mengemuka dan harus dilaksanakan oleh semua lembaga pemerintahan negara yaitu transpransi dan akuntabilitas. Tuntutan transparansi dan akuntabilitas ini harus dipenuhi oleh seluruh lembaga pemerintahan tidak terkecuali Polri.

Berdasarkan data Itwasum Polri, pada tahun 2008 terdapat sekitar 5. 485 surat pengaduan masyarakat mengenai pelaksanaan tugas dan perilaku. Dari 5.485 surat tersebut, $74,13 \%$ adalah surat pengaduan berkenaan dengan pelaksanaan tugas fungsi reserse kriminal, dan sisanya berupa surat pengaduan pada fungsi yang lain dalam struktur organisasi Polri. Pengaduan tersebut berupa:
a. Permohonan tindak lanjut penanganan kasus
b. Permohonan perlindungan hukum
c. Permohonan penegakan hukum 
d. Laporan pengaduan/informasi

e. Korupsi, kolusi dalam penanganan kasus

f. Penyalahgunaan wewenang oleh anggota Polisi dalam proses penyidikan

(Sumber Mabes Polri 2008)

Kompleksnya tugas polisi dalam masyarakat, mengakibatkan terjadinya perubahan dari yang dianggap sebagai seni atau craft menjadi profesi. Profesi berbeda dari craft. Tugas-tugas profesi menuntut adanya kemampuan dan keahlian khusus dari para anggotanya yaitu pengetahuan dan keahlian yang berkaitan dengan ilmu pengetahuan secara konseptual dan teoritikal untuk menganalisa maupun memecahkan masalah-masalah sosial maupun isu-isu penting yang terjadi dalam masyarakat, serta para anggotanya juga dituntut untuk perofesional dalam melaksanakan tugasnya. Orang yang profesional adalah seorang ahli yang memiliki pengetahuan khusus dalam suatu bidang tertentu yang dianggap penting dalam kehidupan masyarakat. Keahliannya diperoleh hanya dari pendidikan tinggi dan pengalaman. Inilah yang menjadi standar obyektif kemampuan profesional yang membedakan profesi dengan craft atau seperti yang dilakukan orang awam.

\section{B. Tinjauan Pustaka}

1. Pengertian Kompetensi

Kompetensi dapat didefinisikan sebagai keseluruhan pengetahuan, kemampuan, keterampilan dan sikap yang diperlukan untuk setiap pekerjaan agar dapat bekerja secara efektif dan efisien dalam lingkungan kerja tertentu, dan ini dapat berupa: (a) kompetensi profesional; (b) kompetensi sosial; (c) konseptual kompetensi (European Union

Yustisia Vol.1 No.1 Januari - April 2012
Leonardo da Vinci Programme. "Strategical Individual")

Kompetensi profesional adalah kompetensi khusus pengetahuan dan keterampilan aktivitas kerja, pengetahuan tentang proses dan teknologi, pasar dan competitor atau produksi dan layanan. Kompetensi sosial dapat didefinisikan sebagai kemampuan untuk berkomunikasi dan bekerja dengan orang-orang, pada umumnya individu-individu dan kemampuan untuk menyesuaikan diri dalam lingkungan sosial. Sedangkan konseptual kompetensi meliputi kompetensi berpikir sistematis, kemampuan untuk mengguanakan model situasi spectrum yang luas dan pengetahuan pengalaman dan jelas mengenai proses tersebut.

Kompetensi profesional dalam perspektif jangka panjang sangat dinamis karena perubahan teknologi yang cepat, tetapi disisi lain, hal ini dapat ditetapkan dengan mudah dan cepat diperoleh. Ciri khas yang menonjol dari profesional kompetensi adalah ditentukan oleh masing-masing fungsional aktivitas kerja, sedangkan sosial dan konseptual adalah kompetensi umum yang diperlukan untuk setiap posisi walaupun dia di dalam perusahaan. Dalam suatu organisasi hal ini memungkinkan organisasi untuk memperoleh keuntungan melalui faktor manusia.

Menurut Spenser dan spenser (1994) dalam P. Hutapea dan N. Thoha bahwa ada tiga komponen utama pembentuk kompetensi yaitu pengetahuan yang dimiliki seseorang, keterampilan dan perilaku individu (P. Hutapea dan N. Thoha, 2008: 28). Pengetahuan merupakan informasi yang dimiliki oleh seseorang yang mengetahui sesuatu hal

Pengaruh Kompetensi Dan Komitmen...

91 
dengan baik. keterampilan adalah kemampuan seseorang untuk melakukan suatu aktifitas atau pekerjaan. Seseorang yang mengetahui sesuatu hal dengan baik belum tentu dapat melaksanakan apa yang diketahuinya. Ahli belum tentu berhasil dalam melaksanakan pekerjaan di bidangnya, dibutuhkan adaya keterampilan lain dalam membantunya untuk dapat mengaplikasikan keahliannya tersebut kepada orang lain dalam hal ini bawahan/ atasannya.

Menurut Boyatzzis (1982), kompetensi didefinisikan sebagai kapasitas yang ada pada seseorang yang bisa membuat orang tersebut mampu memenuhi apa yang disyaratkan oleh oleh pekerjaan dalam suatu organisasi sehingga organisasi tersebut mampu mencapai hasil yang diharapkan (P. Hutapea dan N. Thoha, 2008:4). Woodruffe (1991) mencoba untuk membedakan pengertian antara kompeten dan kompetensi. Kompeten diartikan sebagai konsep yang berhubungan wilayah kerja dimana seseorang dapan menjadi kompeten atau unggul. Sedangkan kompetensi adalah konsep dasar yang berhubungan dengan orang, yaitu menunjukkan dimensi perilaku yang melandasi prestasi unggul tersebut (P. Hutapea dan N. Thoha, 2008: 4-5).

2. Pengertian komitmen

Cascio (1991) mengartikan komitmen organisasi sebagai derajat identifikasi individu tehadap organisasi dan keingingan untuk melanjutkan partisipasinya di dalam organisasi (Natarie, Prihanto, Fricson, 2003: 261). Sheldon (1996) menyebutkan bahwa komitmen organisasi adalah sikap atau suatu orientasi terhadap organisasi yang mengkaitkan identitas pribadi orang tersebut terhadap organisasi (Natarie, Prihanto, Fricson, 2003: 261). Hall (1996) mengartikan komitmen organisasi sebagai suatu proses yang terintegrasi terhadap tujuan organisasi dengan tujuan individu (Natarie, Prihanto, Fricson, 2003: 261). Hariyanto (1996) menyatakan bahwa orang yang mempunyai komitmen organisasi akan menunjukkan identifikasi terhadap organisasi tersebut, nilai-nilai keanggotaan, persetujuan terhadap tujuan- tujuan dan sistem nilai organisasi seta siap sedia bekerja untuk kepentingan organisasinya (Natarie, Prihanto, Fricson, 2003: 262).

Ada tiga jenis komitmen organisasi yang dikemukan oleh Allen dan Meyer (Natarie, Prihanto, Fricson 2003: 262) yaitu :

a. Komitmen afektif (affective commitment)

b. Komitmen berkelanjutan (continue commitment)

c. Komitmen normative (normative commitment)

Komitmen afektif ini berhubungan dengan keterikatan emosional yang dipunyai seseorang dengan organisasi. Seseorang yang memiliki komitmen afektif akan menunjukan kinerja yang lebih baik. Pada komitmen jenis ini, individu tersebut melakukan identifikasi nilai maupun aktivitas organisasi. Semakin kuat identifikasi yang dilakukan akan tejadi internalisasi nilai organisasi yang semakin intensif sehingga dirinya akan semakin terlihat dengan apa yang dilakukan oleh organisasi.

Komitmen berkelanjutan ini berhubungan dengan pertimbangan individu mengenai kerugian-kerugian dan resiko-resiko yang akan dialaminya. Kalau ia mengambil keputusan untuk meninggalkan atau tetap berada di dalam organisasi. Individu yang memiliki komitmen jenis ini, akan melihat untung rugi secara financial dengan cara 
membandingkan organisasi saat ini terhadap organisasi yang memberikan kemungkinan pekerjaan. Jika dilihat dari segi pendapatan masih menguntungkan organisasi yang sekarang, iapun akan tetap bertahan.

Komitmen normatif adalah komitmen yang mengandung nilai moral dan didasarkan pada kewajiban yang dirasakan serta tanggung jawab yang dipikul oleh seorang dalam organisasi. Semakin individu bisa menerima nilainilai organisasi dan semakin sesuai nilai pribadi individu dengan nilai organisasi akan semakin tumbuh kesadaran bahwa ia akan menerima hak-hak tertentu yang diberikan oleh organisasi.

3. Tinjauan Penyelesaian komplain

Menurut Suryono Ekotama dan Sri Wulandari orang tidak puas disebabkan oleh karena dua hal, yaitu karena produknya dan pelayanannya (Suryono Ekotama dan Sri Wulandari, 2009:130131). Orang tidak puas dengan produknya itu mayoritas karena kurang merasakan manfaat produk tersebut. misalnya: produk printer yang bisa melakukan dua kegiatan secara sekaligus yaitu menerima fax dan print, ternyata ketika digunakan barang tersebut hanya bisa fax saja atau print saja. Sedangkan orang tidak puas dengan pelayanan yang tidak memenuhi standar kulaitas yang telah ditetapkan. Pelayanan ini bisa diberikan oleh bagian operasional atau bagian marketing. Contoh pelayanan yang tidak memuaskan dari bagian operasional adalah pelaksanaan perbaikan kerusakan barang yang masih memiliki garansi perusahaan tetapi membutuhkan waktu yang lama untuk perbaikannya.

Lebih lanjut, cara menyelesaikan komplain dapat dilakukan dengan dua cara yaitu cara antisipatif dan cara

Yustisia Vol.1 No.1 Januari - April 2012 represif. Sesuai dengan judul pada penelitian ini maka penulis mengambil cara penyelesain komplain dengan represif. Cara represif dilaksanakan dapat ditempuh dengan: pertama menerima komplain tersebut dengan tenang, jangan terpancing emosi dan berusahalah untuk mengerti situasi serta kondisinya. Ketenangan akan berbuah manis karena bisa menurunkan kadar kemarahan atau kekecewaan orang lain. Kedua, setelah komplain diterima, segera ditindaklanjuti secepatnya. Buatlah waktu standar penyelesaian komplain sesingkat- singkatnya, misalnya maksimal 24 jam terhitung sejak kompalin diterima. Ketiga, komplain harus diselesaikan oleh orang yang tepat sebagaimana jika komplain dicoba untuk diselesaikan oleh orang yang tidak berkompeten, justru dapat menambah kemarahan atas kekecewaan konsumen.

Parson (1989) menawarkan pedoman dalam menyelesaikan konflik (komplain) yaitu (S.L. Tubbs-S. Moss, 2008: 225):

a. Membicarakan kebutuhan masingmasing pihak secara terbuka,

b. Masing-masing pihak harus mendengarkan dengan aktif,

c. Memberikan informasi yang jujur

d. Isi komplain harus fokus kepada sesuatu hal jangan diperluas dengan hal-hal yang lain,

e. Tekankan perilaku-perilaku nyata dalam penyelesaian komplain tersebut sesuai dengan fakta yang ada,

f. Berikan contoh permasalahan yang memiliki persamaan atau perbedaan pada masa lampau,

g. Berikan perencanaan solusi terbaik kepada pihak yang komplain tersebut.

Pengaruh Kompetensi Dan Komitmen... 
4. Pengertian Korban Kejahatan dan Keluarga Korban

Menurut Arif Gosita, korban kejahatan adalah mereka yang menderita fisik, mental, sosial sebagai akibat tindakan jahat mereka yang mau memenuhi kepentingan diri sendiri atau pihak lain (Arif Gosita, 1993:101-202). Mereka yang dimaksud dalam pengertian ini adalah:

a. korban orang perorangan atau korban individual

b. korban yang bukan orang perorangan, misalnya ; suatu badan, organisasi, lembaga.

Pelayanan kepada korban telah lama dilakukan oleh pihak kepolisian tetapi hasilnya kurang maksimal, sehingga hal ini mendatangkan komplain terhadap tindakan kepolisian yang pada akhirnya mengurangi kepercayaan atas tindakantindakan penegakan hukum oleh Penyidik Polri. Ada beberapa bentuk pelayanan kepada korban:

a. Bertanggung jawab langsung (segera) untuk para korban,

b. Menjamin korban dengan pelayanan medis atau pelayanan sosial darurat,

c. Melayani keperluan keluarga para klien yang mendesak,

d. Menjamin tidak terjadinya eksploitasi korban lebih lanjut oleh sistem peradilan kriminal, media massa atau yang lain,

e. Menjamin pemberian bantuan umum dalam keadaan bahaya kepada para klien,

f. Penyediaan teman sementara kepada para korban (pekerja sosial).

Keluarga korban, menurut Kitab Undang-Undang Hukum Pidana, adalah mereka yang mempunyai hubungan darah sampai derajat tertentu atau hubungan perkawinan dengan mereka yang terlibat dalam suatu proses pidana.
Pengertian yang terdapat dalam KUHAP tersebut merupakan pengertian tentang keluarga tersangka. Sedangkan dalam penjelasan Pasal 72 ayat (2) disebutkan bahwa keluarga sedarah dalam garis lurus adalah bapa, kakek, dan sebagainya (ke atas) dan anak/ cucu (ke bawah). Keluarga sedarah dalam garis menyimpang ialah saudara laki- laki, saudara laki-laki, saudara perempuan, saudara ibu atau saudara bapa, baik lakilaki maupun perempuan, anak laki-laki atau anak perempuan dari saudara, dan sebagainya. Banyaknya derajat kekeluargaan sedarah antara dua orang itu dihitung menurut banyaknya kelahiran yang ada antara kedua orang itu. Dengan demikian maka bapa dan anak adalah keluarga sedarah satu derajat, kakek, dan cucu adalah keluarga sedarah dua derajat. Saudara dan saudara adalah keluarga sedarah garis menyimpang tiga derajat. Paman dan keponakan adalah keluarga sedarah garis menyimpang tiga derajat.

Pengertian yang lain mengenai definisi suatu keluarga berasal dari Galvin dan Brommel, yaitu orang-orang yang berbagi kehidupan mereka dalam jangka waktu yang lama; yang terikat oleh perkawinan, darah, atau komitmen, legal atau tidak (Stewart - S. Moss, 2008: 215).

Penelitian ini dilakukan untuk mempelajari hubungan antara kompetensi dan komitmen penyidik terhadap penyelesaian komplain keluarga korban dalam penyidik/ penyidik pembantu menangani kasus yang diterimanya yang diringkas dalam bagan sebagai berikut.

Pengaruh Kompetensi Dan Komitmen... 94 


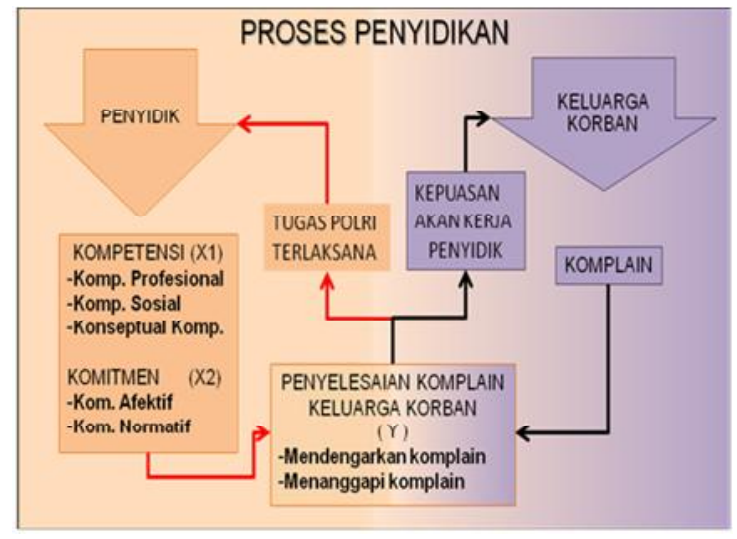

C. Metode Penelitian

1. Jenis Penelitian

Penelitian ini adalah jenis penelitian kuantitatif dengan menggunakan metode survei. Penelitian ini menggunakan 3 (tiga) variabel yaitu penyelesaian komplain sebagai variabel terikat sedangkan kompetensi sebagai variabel bebas pertama dan komitmen sebagai variabel bebas kedua.

Variabel ini diungkap melalui kuesioner yang diberikan peneliti kepada responden dalam hal ini penyidik dengan mengemukakan aspek-aspek kompetensi profesional, kompetensi sosial, dan konseptual kompetensi. Peneliti dalam menilai jawaban responden pada kuesioner dengan menggunakan skala likert (sangat setuju, setuju, ragu-ragu, tidak setuju, dan sangat tidak setuju).

2. Populasi dan Sampling/Subjek Penelitian

Populasi penelitian ini adalah seluruh penyidik yang menangani kasus yang dilaporkan masyarakat antara bulan Juni - November 2009 dan masyarakat yang melapor ke kesatuan jajaran Polres Lampung Utara pada bulan Juni November 2009. Dalam menentukan sampel, peneliti menggunakan cara purposive sampling yaitu kelompok responden yang pertama menggunakan

Yustisia Vol.1 No.1 Januari - April 2012 sampel ideal dan untuk responden masyarakat menggunakan korban yang bertempat tinggal di wialyah kabupaten Lampung Utara karena keterbatasan waktu yang ada untuk penelitian.

3. Teknik Pengumpulan Data

Data primer dikumpulkan dengan menggunakan kuesioner dari responden penyidik dan masyarakat dalam hal ini korban/ keluarga. Selain angket, peneliti juga menggunakan dokumen-dokumen Polres berupa laporan bulanan reskrim bulan Juni - November 2009 dan intel dasar Polres tahun 2009.

4. Metode Analisis Data

Pada awal penelitian ini, peneliti melakukan uji instrumen yaitu uji validitas dan uji reliabilitas. Kemudian dilakukan uji asumsi klasik karena terdiri atas dua variabel independen. Setelah itu, terhadap data dilakukan uji regresi. Perhitungan analisis data hasil penelitian dilakukan dengan menggunakan program SPSS (Statistical Package for Social Science) version 17.0.

\section{Hasil Penelitian dan Pembahasan}

1. Hasil Penelitian

Dari proses penelitian ini diperoleh gambaran subjek penelitian sebagai berikut:

a. Responden penyidik

Penyidik Polres Lampung Utara terdiri atas pria 114 orang dan wanita 2 orang; umur 20-30 tahun adalah sebanyak 75 orang, 31-45 tahun sebanyak 31 orang, dan 46-58 sebanyak 10 orang; 102 penyidik berlatar belakang pendidikan SMU, STM sebanyak 7, dan S1 sebanyak 7 penyidik; penyidik yang berlatar belakang sekolah tamtama sekolah calon bintara 3 orang sedangkan Penyidik yang berlatar belakang sekolah calon bintara adalah 113 orang;

Pengaruh Kompetensi Dan Komitmen... 95 
pendidikan kejuruan reskrim berjumlah 34 orang, intel: 5 orang, lantas: 2 orang, samapta: 4 orang, lainnya: 10 orang, dan belum dikjur: 61 orang; penyidik yang bermasa dinas 1-3 tahun: 32 orang, 3-6 tahun: 23 orang, dan $>6$ tahun: 61 orang; Penyidik yang berpangkat bripda: 31 orang, briptu: 42 orang, brigadir: 22, Bripka: 10, Aipda: 3, dan Aiptu: 8 orang.

Tabel 1

Distribusi tanggapan kompetensi dan komitmen Penyidik

\begin{tabular}{|c|c|c|c|c|c|c|c|c|c|c|c|}
\hline \multirow{3}{*}{ NO } & \multirow{3}{*}{ VARIABEL } & \multicolumn{10}{|c|}{ TANGGAPAN RESPONDEN } \\
\hline & & \multicolumn{2}{|c|}{ SS } & \multicolumn{2}{|c|}{$\mathrm{S}$} & \multicolumn{2}{|c|}{$\mathrm{R}$} & \multicolumn{2}{|c|}{ TS } & \multicolumn{2}{|c|}{ STS } \\
\hline & & $\mathrm{V}$ & $\%$ & $\mathrm{~V}$ & $\%$ & $\mathrm{~V}$ & $\%$ & $\mathrm{~V}$ & $\%$ & $\mathrm{~V}$ & $\%$ \\
\hline 1 & Kompetensi (X1) & 1066 & 33 & 729 & 27 & 591 & 20 & 45 & 13 & 5 & 7 \\
\hline 2 & Komitmen (X2) & 932 & $\begin{array}{c}38, \\
2\end{array}$ & 729 & 30 & 720 & 29,6 & 55 & 2,2 & 0 & 0 \\
\hline
\end{tabular}

Sumber : Data Primer yang diolah, 2009

Berdasarkan tabel di atas menunjukan bahwa secara keseluruhan kompetensi Penyidik Pembantu Polres Lampung Utara dan jajaran adalah baik yaitu $73,7 \%, 24,2 \%$ berada pada nilai kompetensi yang biasa-biasa saja dan $2,1 \%$ memiliki nilai kompetensi yang rendah. Hal ini menunjukan bahwa secara umum kompetensi Penyidik Pembantu Polres Lampung Utara dan jajaran dapat dikategorikan sangat baik.

Pada tabel di atas juga dapat dilihat komitmen Penyidik Pembantu Polres Lampung Utara dan jajaran dalam melaksanakan tugas penyidikan dan penyelidikan yaitu $68,2 \%$ termasuk dalam kategori sangat baik, 29,6\% dikelompok dalam kategori baik dan sisanya sebesar $2,2 \%$ dapat dikategorikan sebagai Penyidik Pembantu dengan komitmen yang rendah. Hal tersebut memberikan bahwa komitmen Penyidik Pembantu Polres Lampung Utara dan jajaran adalah sangat baik.

b. Responden keluarga/ korban

Responden masyarakat (keluarga/ korban) Lampung Utara terdiri dari pria 290 orang dan wanita 84 orang; masyarakat yang berusia antara 10-21 tahun: 58 orang, umur 22-35: 182 orang, umur 36-42: 50 orang, dan umur 43-75: 84 orang; responden yang berpendidikan SD sejumlah 24 orang, SLTP: 64 orang, SMU: 238 orang, STM: 13 orang, D3: 7 orang, S1: 25 orang,dan S2; 3 orang; masyarakat yang berpekerjaan $\mathrm{TNI} /$ POLRI adalah 7 orang, wiraswasta: 53 orang, karyawan: 137 orang, pengangguran: 48 orang, mahasiswa/ pelajar: 38 orang, PNS: 39 orang, dan tani: 52 orang. 
Tabel 2

Distribusi Tanggapan Keluarga/ Korban dalam Penyelesaian Komplain

\begin{tabular}{|c|c|c|c|c|c|c|c|c|c|c|}
\hline \multirow{3}{*}{ VARIABEL } & \multicolumn{10}{|c|}{ TANGGAPAN RESPONDEN } \\
\hline & \multicolumn{2}{|c|}{ SS } & \multicolumn{2}{|c|}{$\mathrm{S}$} & \multicolumn{2}{|c|}{$\mathrm{R}$} & \multicolumn{2}{|c|}{ TS } & \multicolumn{2}{|c|}{ STS } \\
\hline & $\mathrm{V}$ & $\%$ & $\mathrm{~V}$ & $\%$ & $\mathrm{~V}$ & $\%$ & $\mathrm{~V}$ & $\%$ & $\mathrm{~V}$ & $\%$ \\
\hline $\begin{array}{l}\text { Penyelesaian } \\
\text { Komplain (Y) }\end{array}$ & 2207 & 39,34 & 1754 & 31,27 & 1532 & 27,3 & 115 & 2,05 & 2 & 0,04 \\
\hline
\end{tabular}

Sumber : Data Primer yang diolah, 2009

Berdasarkan data yang terdapat dalam tabel diketahui bahwa penyelesaian komplain masyarakat dalam hal ini korban kejahatan termasuk dalam kategori sangat. Secara kuantitatif nilainya adalah 70,61\% (39,34\% + $31,27 \%$ ). Sedangkan penyelesaian komplain yang baik sebesar $27,30 \%$ dan penyelesaian komplain rendah sebesar $2,05 \%$ serta penyelesaian komplain sangat rendah adalah sebesar $0,04 \%$.

Dalam hal ini tanggapan masyarakat Lampung Utara mengenai penyelesaian komplain Penyidik Polres Lampung Utara dan jajaran masuk dalam kategori sangat baik.

c. Hasil Uji Asumsi Klasik

1) Uji Multikolonieritas

Berdasarkan hasil besaran

korelasi antara variabel independen sebesar -0,844 atau sekitar 84,4\%.

Oleh karena korelasi ini masih berada di bawah 95\%, maka dapat dikatakan tidak terjadi multikolonieritas yang serius.

Hasil penghitungan tolerance menunjukan tidak ada variabel independen yang memiliki nilai tolerance $<0,10$ yang berarti tidak ada korelasi antara variabel independen yang nilainya lebih dari 95\%. Hasil penghitungan VIF juga menunjukan hasil yang sama yaitu tidak ada suatu variabel yang memiliki nilai VIF $>10$. Jadi dapat disimpulkan bahwa tidak ada multikolonieritas antara variabel independen dalam model regresi tersebut.

2) Uji Heteroskedastisitas

Berdasarkan grafik scatterplots terlihat bahwa titik-titik menyebar secara acak serta tersebar baik di atas maupun di bawah angka 0 pada sumbu Y. Hal ini dapat disimpulkan bahwa tidak terjadi heteroskedastisitas pada model regresi, sehingga model regresi layak dipakai untuk memprediksi variabel penyelesaian komplain berdasarkan variabel independen dan variabel komitmen.

3) Uji Normalitas

Uji normalitas dengan menggunakan prinsip, $\mathrm{Z}$ hitung $>\mathrm{Z}$ tabel, maka model regresi tersebut terdistribusi normal. Dengan tingkat kesalahan 0,05 , maka nilai $\mathrm{Z}$ tabel $=$ $\pm 1,96$ didapatkan bahwa $Z$ hitung $>$ $\bar{Z}$ tabel. Berdasarkan penghitungan 
SPSS pada tabel tersebut di atas didapatkan bahwa nilai K-S adalah 1.306 dengan signifikan pada 0,066. Karena signifikannya berada di atas 0,05 , hal ini berarti data residual terdistribusi normal pada $\alpha=0,05$. Berdasarkan dua jenis perhitungan di atas ditemukan bahwa model regresi tersebut berdistribusi normal, sehingga dapat dilanjutkan dengan melakukan analisa regresi.

4) Uji Regresi

Uji regresi dilakukan dengan melakukan uji koefisien determinasi, $\mathrm{F}$ test, dan $\mathrm{t}$ Test. Berdasarkan penghitungan SPSS ver 17.0 diperoleh koefisien determinasi keseluruhan (adjusted R squared) sebesar 0,769. Angka ini menunjukan bahwa kompetensi dan komitmen secara bersama-sama mampu menjelaskan variasi variabel dependen yaitu penyelesaian komplain sebesar 76,9\% selebihnya sebesar 23,1\% dijelaskan oleh variabel lain di luar model regresi ini.

Uji ini dapat dilihat pada nilai $\mathrm{F}$ test sebesar 621.178 dan signifikan pada 0,000 yang berarti variabel independen yaitu kompetensi (X1) dan Komitmen (X2) secara simultan atau bersama mempengaruhi variabel dependen yaitu penyelesaian komplain (Y).

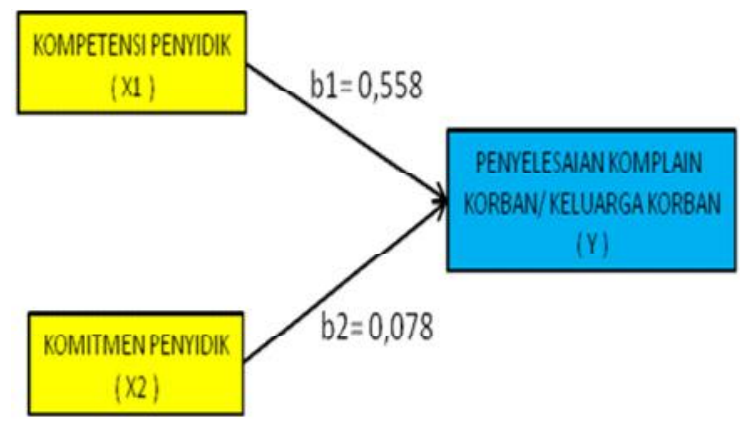

Berdasarkan gambar di atas juga, Koefisien regresi untuk variabel kompetensi (X1) adalah 0,558 (a1) dan sebesar 0,078 (a2) untuk variabel komitmen yang menunjukan pengaruh masingmasing variabel tersebut terhadap variabel penyelesaian komplain keluarga/ korban.

2. Pembahasan

Hasil penelitian menunjukan bahwa kompetensi dan komitmen tidak dapat dipisahkan antara satu sama lain karena mempunyai pengaruh yang signifikan dan kuat terhadap penyelesaian komplain keluarga/ korban.

Dari kedua variabel tersebut, variabel kompetensi yang paling dominan dalam memberikan pengaruh terhadap penyelesaian komplain yaitu dengan nilai koefisien determinasi parsial (r2) sebesar 43,03\%, sedangkan variabel komitmen hanya memberikan pengaruh sebesar $1,66 \%$. Orang yang memiliki kompetensi adalah orang yang memiliki prestasi yang lebih baik daripada rekan-rekan kerjanya (Parulian dan Nurianna, 2008: 27 - 28). Pengaruh ini akan lebih kuat lagi ketika variabel kompetensi dan komitmen secara bersama-sama memberikan kontribusi terhadap penyelesaian komplain sebesar $76,9 \%$. Ketika faktor yang disebutkan di atas yaitu faktor kebijakan pimpinan, faktor individu dan faktor lingkungan masyarakat dalam kondisi yang baik maka akan baik juga penyelesaian komplain yang dilakukan oleh penyidik/penyidik pembantu terhadap masyarakat (keluarga/ korban).

a. Pengaruh kompetensi penyidik terhadap penyelesaian komplain keluarga/ korban

Variabel kompetensi memiliki nilai koefisien regresi sebesar 0,558 yang

Pengaruh Kompetensi Dan Komitmen... 98 
berarti bahwa jika kompetensi penyidik bertambah 1 satuan maka penyelesaian komplain akan meningkat ke arah yang lebih baik sebesar 0,558 satuan. Dengan nilai signifikansi $0,000 \quad(\alpha=0,05)$ kompetensi signifikan untuk menjelaskan variabel penyelesaian komplain. Berdasarkan hasil penelitian, variabel kompetensi penyidik memiliki nilai koefisien determinasi parsial (r2) sebesar 43,03\% artinya variabel kompetensi memberikan kontribusi sebesar 43,03\% dalam menjelaskan variabel penyelesaian komplain. Hal ini sesuai teori Andre Karlsson dan Lars Narden (2007) yang mengatakan bahwa dengan memiliki kompetensi yang tinggi seseorang dapat dengan mudah melaksanakan suatu kegiatan tertentu apabila dibanding dengan orang yang tidak memiliki kompetensi. Dengan kata lain, seorang penyidik yang memiliki kompetensi yang baik dalam penyidikan akan dapat dengan mudah menyelesaikan komplain keluarga/ korban. Heath dan Tversky (1991) dalam Anders Karlson dan Lars Norden (2007) menyatakan bahwa orang akan lebih berani bertaruh berdasarkan penilaian mereka sendiri dalam daerah dimana mereka menganggap diri mereka lebih memiliki kompetensi. Kompetensi menurut Boyatzis (1982) didefinisikan sebagai kapasitas yang ada pada seseorang yang bisa membuat orang tersebut mampu memenuhi apa yang diisyaratkan oleh pekerjaan dalam suatu orgnanisasi sehingga organisasi tersebut dapat mencapai hasil yang diharapkan (Hutapes dan Toha, 2008: 4). Komplain harus diselesaikan oleh orang yang tepat sebab jika komplain tidak diselesaikan oleh orang yang memiliki kompetensi, justru dapat menambah kemarahan atau kekecewaan konsumen (Ekotama dan Sri Wulandari, 2009: 133). b. Pengaruh komitmen penyidik terhadap penyelesaian komplain keluarga/ korban

Variabel komitmen memiliki nilai koefisien regresi sebesar 0,078 yang berarti bahwa jika komitmen penyidik bertambah satu satuan maka penyelesaian komplain akan bertambah baik sebesar 0,078 satuan. Dengan nilai signifikansi 0,013 , komitmen signifikan untuk menjelaskan variabel penyelesaian komplain $(\alpha=0,05)$. Berdasarkan hasil penelitian, variabel komitmen penyidik memiliki nilai koefisien determinasi parsial (r2) sebesar $1,66 \%$ artinya variabel komitmen memberikan kontribusi sebesar $1,66 \%$ dalam menjelaskan variabel penyelesaian komplain. Berarti variabel komitmen berpengaruh terhadap tingkat penyelesaian komplain, walaupun nilainya sangat kecil. Dalam hal ini perilaku komitmen diartikan sebagai perilaku penyidik yang diwajibkan harus komit kepada aturan yang ada di dalam organisasi Polri tersebut, sedangkan afektif komitmen adalah adanya kesadaran untuk melaksanakan tugas/ prosedur yang ada dengan tidak tulus tanpa paksaan baik secara psikis maupun fisik.

Pendapat yang serupa juga dikatakan oleh Kepala Satuan Reskrim Polres Lampung Utara Adi Sumirat yang menyatakan bahwa sebagian besar anggota reskrim Polres Lampung Utara tidak bersikap proaktif terhadap tugas yang seharusnya dijalankan sebagai seorang penyidik. Tanpa adanya perintah atau arahan maka penyidik tersebut tidak akan melaksanakan tugasnya, ataupun kalau yang bersangkutan melaksanakan tugas tersebut dilaksanakan tidak sungguh-sungguh.

Pengaruh Kompetensi Dan Komitmen... 101 


\section{E. Simpulan}

Berdasarkan hasil penelitian dan pembahasan, maka dapat diambil simpulan:

a. Pengaruh variabel kompetensi dan komitmen adalah signifikan terhadap variabel penyelesaian komplain. Ketika seorang penyidik memiliki kompetensi dan komitmen yang baik maka penyelesaian komplain yang diberikan kepada masyarakat juga akan baik. dengan begitu masyarakat akan puas dan memberikan citra yang positif terhadap kinerja yang dilakukan oleh penyidik/penyidik pembantu.

b. Kompetensi penyidik memiliki pengaruh yang signifikan terhadap penyelesaian komplain yang diterima oleh keluarga/ korban. Ketika kompetensi seorang penyidik/penyidik pembantu rendah maka akan rendah juga penyelesaian komplian yang diterima oleh masyarakat dalam hal ini keluarga/ korban. Hal ini secara simultan akan mengakibatkan jeleknya citra yang diberikan oleh masyarakat terhadap kinerja dari penyidik/penyidik pembantu.

c. Komitmen penyidik memiliki pengaruh yang signifikan terhadap penyelesaian komplain yang dirasakan oleh keluarga/ korban. Komitmen yang baik dari penyidik/penyidik pembantu memberikan artinya bahwa penyidik/penyidik pembantu yang memiliki komitmen yang baik tersebut akan mampu memberikan penyelesaian komplain yang baik juga terhadap masyarakat (keluarga/korban). Dengan begitu, masyarakat menilai positif terahdap kinerja dari penyidik/penyidik pembantu tersebut sehingga citra penyidik/penyidik Pembantu akan positif.

\section{F. Saran}

Adapun saran-saran yang diajukan oleh penulis dari penelitian yang telah dilakukan antara lain:

a. Kompetensi dan komitmen penyidik harus dipertahankan karena sudah baik. Kompetensi dan komitmen penyidik tersebut dapat dipertahankan dengan cara memberikan pengawasan yang sewajarnya. Tidak perlu mengadakan pengawasan melekat terhadap penyidik yang bersangkutan dalam melakukan penyidikan.

b. Secara parsial kompetensi penyidik yang sudah baik tersebut agar dipertahankan kalau bisa ditingkatkan. Untuk mempertahankan dan meningkatkan kompetensi tersebut dapat dilakukan dengan tindakan penguatan, pengulangan, dan pengarahan terhadap penyidik secara rutin. Sedangkan untuk variabel komitmen penyidikan yang memberikan pengaruh yang lemah terhadap variabel penyelesaian komplain harus ditingkatkan dengan cara melaksanakan pengawasan yang ketat dan pengarahan yang terus menerus. Setiap penyidik ini melaksanakan tugas harus diawasi dan selalu harus diarahkan agar tidak terjadi disorientasi tugas.

c. Penelitian yang dilakukan ini hanya difokuskan kepada pelaksana di lapangan, dalam hal ini para Penyidik/ Penyidik Pembantu yang langsung bersentuhan dengan masyarakat, diperlukannya penelitian lebih lanjut terhadap komitmen atasan penyidik dalam hal 
ini Kapolres dan Kasat Reskrim. Hal ini terkait dengan ditemukannya komitmen yang mempunyai nilai yang relative kecil terhadap penyelesaian komplain yang dimiliki oleh penyidik/penyidik Pembantu yang melakukan penangan suatu perkara. Apakah komitmen yang dimiliki oleh atasan penyidik/penyidik pembantu memiliki pengaruh terhadap komitmen yang ada pada penyidik/penyidik pembantu. 


\section{DAFTAR PUSTAKA}

Arif Gosita. S.H. 1993. Masalah Korban Kejahatan (Kumpulan Karangan). Jakarta: Akademika Pressindo.

European Union Leonardo da Vinci Programme. "Strategical Individual" . http://www.sicdevelopment.org.

Natarie Yuliane, Sutyas Prihanto dan Frikson C. Sinambela. 2003. "Rasa Percaya, Komitmen Organisasi, dan Rasa Berdaya Tim (Empowered Team) pada Karyawan Instansi Pemerintah Surabaya". Anima, Indonesian Psychological Journal, Vol. 18 No.03, Surabaya: 95A.

Parulian Hutapea dan Dr. Nurianna Thoha. 2008. Kompetensi Plus, Jakarta: PT. Gramedia Pustaka Utama.

Suryono Ekotama dan Sri Wulandari. 2009. Seni Menjual dengan Hati, Jakarta : Media Pressindo.

R. Soesilo. 1993. Kitab Undang-Undang Hukum Pidana (KUHP), Bogor: Politeia.

Undang-Undang Republik Indonesia Nomor 2 Tahun 2002 Tentang POLRI

Undang-Undang Dasar Republik Indonesia 1945 (Amandemen keempat) 